\title{
Productivity of Calliandra calothyrsus, Indigofera zollingeriana and Gliricidia sepium on Acid Soil in the Greenhouse
}

\author{
Herdiawan I, Sutedi E \\ Balai Penelitian Ternak, PO Box 221, Bogor 16002 \\ E-mail: herdiawanmaliq@gmail.com \\ (received 13-01-2015; revised 27-04-2015; accepted 18-05-2015)
}

\begin{abstract}
ABSTRAK
Herdiawan I, Sutedi E. 2015. Analisis produktivitas tanaman Caliandra calothyrsus, Indigofera zollingeriana dan Gliricidia sepium pada lahan kering masam di rumah kaca. JITV 20(2): 105-114. DOI: http://dx.doi.org/10.14334/jitv.v20i2.1165

Tanah masam umumnya kurang baik bagi budidaya tanaman, tidak terkecuali untuk leguminosa pohon karena mengandung $\mathrm{Al}^{3+}$ dan $\mathrm{Mn}^{2+}$. Kedua mineral tersebut mungkin bersifat toksik bagi pertumbuhan dan produksi tanaman Caliandra calothyrsus, Indigofera zollingeriana, dan Gliricidia sepium yang umumnya digunakan sebagai hijauan pakan. Penelitian ini bertujuan untuk membandingkan daya toleransi dan produktivitas ketiga jenis tanaman pada tanah masam. Tiga jenis tanaman ditanam di rumah kaca dengan media tanam tanah Ultisol dengan $\mathrm{pH}$ 4,57 yang diambil dari perkebunan kelapa sawit Sei-Putih, Medan. Percobaan menggunakan 3 jenis tanaman sebagai perlakuan dan diulang sebanyak 12 kali dengan menggunakan Rancangan Acak Lengkap (RAL). Data dianalisis dengan sidik ragam (ANOVA) menggunakan metode SPSS, program exel, dilanjutkan dengan uji LSD apabila terdapat data yang berbeda nyata. Peubah yang diamati adalah morfologi tanaman, konsentrasi $\mathrm{Al}^{3+}$ pada jaringan tanaman, tinggi tanaman, diameter batang, jumlah percabangan pada batang, panjang akar, produksi tanaman, kandungan nutrisi, energi, dan kecernaan (in-vitro). Konsentrasi $\mathrm{Al}^{3+}$ pada daun, batang dan akar nyata paling tinggi ditemukan pada G. sepium, sedangkan konsentrasi terendah pada I. zollingeriana. G. sepium tumbuh lebih kerdil, diameter batang tidak berbeda dengan $C$. calothyrsus, tetapi keduanya lebih rendah dari I. zollingeriana. Jumlah percabangan pada I. zollingeriana, nyata lebih tinggi dibandingkan dengan G. sepium. Panjang akar C. calothyrsus tidak berbeda nyata dengan I. zollingeriana, sedangkan akar G. sepium lebih pendek. Nodulasi akar hanya terbentuk pada I. zollingeriana. Produksi biomasa dan kandungan protein tertinggi, serta nilai kecernaan terbaik dicapai pada I. zollingeriana. Berdasarkan data kandungan $\mathrm{Al}^{3+}$ pada jaringan daun, batang dan akar I. zollingeriana nyata lebih toleran terhadap tanah masam (Ultisol). Daya toleransi tanaman berpengaruh terhadap pertumbuhan, produksi biomasa, kandungan nutrisi, dan nilai kecernaan yang lebih baik.
\end{abstract}

Kata Kunci: Leguminosa Pohon, Tanah Masam, $\mathrm{Al}^{3+}$

\begin{abstract}
Herdiawan I, Sutedi E. 2015. Productivity of Calliandra calothyrsus, Indigofera zollingeriana and Gliricidia sepium on acid soil in the greenhouse. JITV 20(2): 105-114. DOI: http://dx.doi.org/10.14334/jitv.v20i2.1165

Acid soil which contains $\mathrm{Al}^{3+}$ and $\mathrm{Mn}^{2}$ is generally unfavorable for crop including the tree legumes. The minerals are toxic to the plants resulted minimalization of growth and crop production. Caliandra calothyrsus, Indigofera zollingeriana, and Gliricidia sepium were tree legumes those are generally used for forage. The aim of this study was to compare their tolerancy to $\mathrm{Al}^{3+}$ and growth production on acid soil. The plants were grown in ultisol soil with $4.57 \mathrm{of} \mathrm{pH}$ collected from Palm Oil plantation, Sei-Putih, Medan. The experiment was carried out using completely randomized design (CRD) with kind of plants as the treatment and 12 times replication. The data were analyzed by ANOVA using the SPSS and excel program, followed by LSD test when the data was significantly difference. Variables measured were plant morphology, concentration of $\mathrm{Al}^{3+}$ in the plant tissues, plant height, stem diameter, number of stem branches, root length, plant production, nutrient content, energy and in vitro digestibility. The highest $\mathrm{Al}^{3+}$ contents in leaves, stem and root were significantly observed in those G. sepium, while the lowest contents was observed from those of I. zollingeriana. G. sepium was the most dwarf plant and its stem diameter was comparable with the one of $C$. calothyrsus, but was lower than that of I. zollingeriana. The highest number of branches was significantly observed in I. zollingeriana, while the lowest one was at G. sepium. The root length of $C$. calothyrsus was comparable with that of I. zollingeriana, while G. sepium root was the shorthest one. Root nodulation was only formed at $I$. zollingeriana. The highest biomass production was observed at I. zollingeriana which also had highest protein content and the best digestibility. Data from $\mathrm{Al}^{3+}$ concentration in tissues of leaves, stems and roots showed that I. zollingeriana was the most tolerant plant to acid soils. This tolerancy also affected higher plant growth, biomass production, nutrient concentration, and digestibility.
\end{abstract}

Key Words: Tree Legume, Acid Soil, $\mathrm{AI}^{3+}$ 


\section{INTRODUCTION}

Large acid dry soil potential in Indonesia is a chance to produce various crop commodities (food crops, estates, or livestock's feed crops). Several soils that generally had acid $\mathrm{pH}$ in the dry area were Entisols, Inceptisols, Ultisols, Oxisols, and Spodosols, especially for area, which has wet climate with high rainfall. The largest ordos were Ultisol and Inceptisols, with its dominan spreading was in the Sumatera, Kalimantan, and Papua (Mulyani et al. 2004). Utisol was one of soil types which widely spreaded reaching 45794000 ha or about $25 \%$ of total of Indonesian land, which was widely used as estate area, among other oil palm, rubber, and industry plantation (Subagyo et al. 2004).

Concentration of high alumunium in the form of $\mathrm{Al}^{3+}$ was one of limiting factors of crops cultivation on the acid $(\mathrm{pH} \leq 5.5)$ land which inhibited crop's growth and production (Gergichevich et al. 2010). In line with it, Sopandie (2006) said that reactive alumunium $\left(\mathrm{Al}^{3+}\right)$ was released from soil in the form of $\mathrm{AI}(\mathrm{OH})^{2+}$ and $\mathrm{AI}(\mathrm{OH})^{3+}$ which often become toxic to all agricultural crops, because of the AI ion inhibited root growth quickly in concentration of micromolar. Kinraide \& Hagerman (2010) also said that alumunum was very strong toxic to the crop and would inhibit their growth, decrease biomass production and overall crop yield. Ryan \& Delhaize (2010) said that $\mathrm{Al}^{3+}$ toxicity in acid land $(\mathrm{pH} \leq 5.5)$ was main factor of stress to the crop, especially to the root tissue of crop that directly contacted with the environtment (Rizonsphere). According to Rengel \& Zhang (2003), decreasing of root growth was one of early and very clear simpthom of AI toxication in micromolar $(\mu \mathrm{M})$ concentration limit which boosted the decreasing of water and nutrient absorption capacity. The alumunium able to inhibit essential nutrient absorption to the crops such as Ca, $\mathrm{Mg}, \mathrm{Mn}, \mathrm{Fe}, \mathrm{Mo}$, and P (Poschenrieder et al. 2008).

Mora et al. (2006) said that AI toxicity changed physiology and biochemistry process of the crop, and its consequence affected its productivity. In despite of $\mathrm{Al}$ inhibited process of metabolism and crops growth, but until a certain threshold, tolerant crops (Utama et al. 2005) could tolerate AI effect. According to Wang et al. (2006), several crops were tolerant to aluminum stress because they eliminated AI, so that was not toxic and affected growth and productivity of the crops. Based on Polania et al. (2010), in the genotype of the tolerant crops showed better rooting performance and expected would produce higher biomass. In the context of the sustainable forage on the acid dry land, it needed acid- tolerant foragrs. Several forages included in Fabaceae family had good enough tolerance to the dry acid land (Tjelele 2006). C. calothyrsus, I. zollingeriana, and $G$. sepium were tree leguminous which could be used as forage in the acid soil of estate area, so that needed to be observed extent to which its tolerance and productivity.

\section{MATERIALS AND METHODS}

This research was carried out at greenhouse of Agrostology, Ciawi Indonesian Research Institute for Animal Production (AIAT) using 3 tree leguminous ( $C$. calothyrsus, G. sepium, dan I. zollingeriana). Growing media used in this research was Ultiosl acid soil from oil palm plantation, Medan with chemical composition of the soil was presented in the Table 1.

Each of the three crops was planted in plastic pot (40 and $50 \mathrm{~cm}$ of diameter, which its base was coated by plastic with $40 \mathrm{~cm}$ of diameter to hold water spilled when watering. Planting process was started by seeding of the three crops on the seeding tray for 4 weeks old. After 4 weeks, the seeds were moved into small polybags until 8 weeks old and further, those seedling were moved into plastic pots which were fulfilled by 40 $\mathrm{kg}$ of planting media. Watering was done once of 2 days. Volume of watering was adapted with determination result of field capacity (FC). Morphology of crops and root were observed visually at the end of this study. Dry weight production of the crops was done for 44 weeks in every 90 days of harvest day using digital scale. Crops growth was measured in every 2 weeks using meter with $1 \mathrm{~cm}$ of scale and digital Vernier calipers. $\mathrm{Al}^{3+}$ concentration and nutrient composition was determined from proximate analysis in the nutrition laboratory of IRIAP.

The experiment was carried out using completely randomized design (CRD) with kind of plants as the treatment and 12 times replication. The data were analyzed by ANOVA using the SPSS and excel program, followed by LSD test when the data was significantly difference. Variables measured were plant morphology, concentration of $\mathrm{Al}^{3+}$ in the plant tissues, plant height (height, stem diameter, number of branches, root length), plant production (dry weight of leaves, branches and stems, biomass, and ratio of stem/leave) nutrient content (crude protein, crude fiber, fat, dust, $\mathrm{Ca}$, and $\mathrm{P}$ ), energy and in vitro digestibility of dry and organic materials. 
Table 1. Analysis result of soil from oil palm plantation, Sei Putih, Medan

\begin{tabular}{|c|c|c|c|c|}
\hline \multirow{2}{*}{ Composition } & \multicolumn{4}{|c|}{ Soil Samples } \\
\hline & $\mathrm{A}$ & B & $\mathrm{C}$ & Average \\
\hline $\mathrm{pH}$ & 4.40 & 4.80 & 4.50 & 4.57 \\
\hline \multicolumn{5}{|c|}{ Organic material (\%) } \\
\hline Carbon $(\mathrm{C})$ & 1.64 & 1.27 & 1.56 & 1.49 \\
\hline Nitrogen $(\mathrm{N})$ & 0.16 & 0.12 & 0.15 & 0.14 \\
\hline $\mathrm{C} / \mathrm{N}$ ratio & 10.02 & 10.06 & 10.04 & 10.04 \\
\hline \multicolumn{5}{|c|}{ Anion exchange rate } \\
\hline $\mathrm{Ca}$ & 7.56 & 6.99 & 7.73 & 7.43 \\
\hline $\mathrm{Mg}$ & 1.44 & 2.41 & 1.32 & 1.72 \\
\hline $\mathrm{K}$ & 0.57 & 0.48 & 0.43 & 0.49 \\
\hline $\mathrm{Na}$ & 0.49 & 0.51 & 0.49 & 0.50 \\
\hline $\mathbf{A l}^{3+}$ & 1.36 & 1.15 & 1.27 & 1.26 \\
\hline
\end{tabular}

*Analyzed at Soil Laboratory, Indonesian Center for Agricultural Technology Assessment and Development (ICATAD) in 2013

\section{RESULT AND DISCUSSION}

\section{Morphology of the crops in the acid soil}

Based on observation result, morphologically, $I$. zollingeriana was better than $C$. callothyrsus and $G$. sepium, such as shave and color of leaves, stems, and the number of brunches. Stem of the $C$. callothyrsus seemed thicker than I. zollingeriana and G. sepium, likewise the leaves color of the I. zollingeriana seemed greener than $C$. callothyrsus and $G$. sepium which were yellowish and dry out at the tip of the leaves. G. sepium was stunted growth with thin stem, and in almost the leaves had tallow spot, whereas $C$. callothyrsus tree grown spindly and almost all leaves had yellow spot (Figure 1.).

Suntoro et al. (2014) said that the condition of the soil $\mathrm{pH}$ is low (acidic), the solubility of some minerals not available to needed for the chlorofil formation.

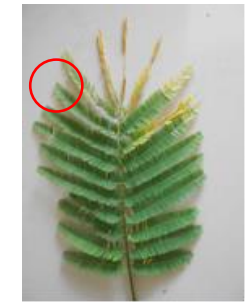

C. calothyrsus

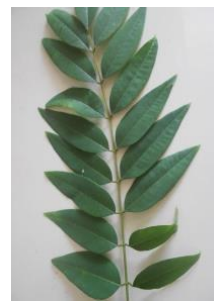

I. zollingeriana

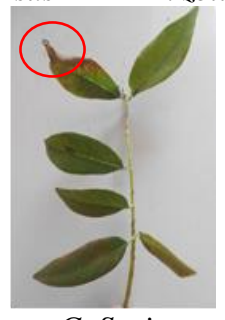

G. Sepium

= yellow spot

Figure 1. Morfology of leaf in the acid soil

Consequently decreased leaf chlorophyll, leaf color yellow spots which in turn is inhibited the process of photosynthesis rate. Thus the amount of photosynthate produced is very low, this determines the lower plant growth. This showed that both of the I. zollingeriana and $C$. callothyrsus were poisoned by micro content. Sumarno (2005) said that clear symptoms of crops that sensitive to the acid soil were very stunted growth, brownish yellow leaves, very limited root growth, minimal flower-shaped, and minimal seed number, very low productivity or failed to produce seeds (Figure 2).

According to Wang et al. (2006) poisoned plant by AI would has nutrient deficiency, such as $\mathrm{P}, \mathrm{Ca}, \mathrm{Mg}$, $\mathrm{Mn}$, and $\mathrm{Fe}$, so that morphologically was more stunted and its productivity was low. Schaberg et al. (2006) found the same thing in the sugar maple plant that showed high AI content affected low $\mathrm{Ca}$ and restricted plant growth. Sumarno (2005) said that the growth of soybean plant on acid soil was suffer due to abiotic and biotic stresses, such as (a) vegetative growth was hampered because of macro and micro deficiency; (b) AI or Mn poisoning; (c) nodule formation was inhibited; (d) the plant was easier to get drought stress; and (e) root growth was inhibited. Furthermore, it was said that very clear symptoms were very stunted growth, brownish yellow leaves, very limited root growth, minimal flower-shaped, and minimal seed number, very low productivity or failed to produce seeds. Although Al concentrations in the nutrient solutions are within the micromolar range $(25-1,600$ $\mu \mathrm{M})$, they are sufficient to induce morphological and physiological damage in some crops, and even more significant changes in seedlings (Rengel 1996). Altoxicity is an important stress factor for plants, limiting plant growth, development and the subsequent performance of commercial crops (Poschenrieder et al. 2008); Rout et al. 2001). 


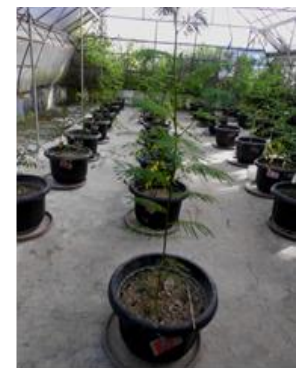

C. calothyrsus

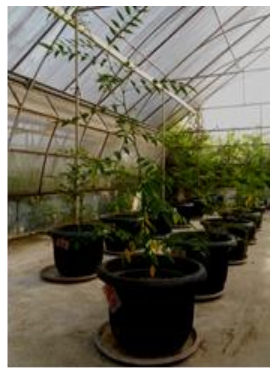

I. zollingeria na

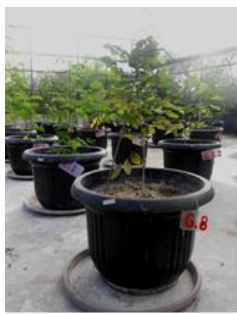

G. sepium
Figure 2. Morphology of the crops in the acid soil

\section{Root morphology on the acid soil}

Morphology chance of $C$. callotyrsus root was not clearly seen, the roots grown lengthwise, feathers grown normally, but nodule was not found in the main root or the branches. Root morphology of $I$. zollingeriana showed normal growth, the most root hair in every main root or branches and nodule was formed. Root morphology chance was occurred in the $G$. sepium, that was abnormally growth, shorter with slightly root feather and only grown at the root tip (Figure 3).

No formation of nodule on the root of $C$. calothyrsus and $G$. sepium was one indicator of the $\mathrm{AL}^{3+}$ poisoning consisted of root cells damage, so that root did not grow well aside from poisoning the environment (rhizosfer) that affected root microbe (rhizobium) growth.

As noted by Taiz \& Zeiger (2006) that growth of crops rooting was highly depended on growth environment of the crops and its growth was controlled by crop's activity. Factors affected the soil environment among other factor of physic, biology, and chemistry of soil. The first symptom came up from AI poisoning was short rooting system as a result of cell extension inhibition (Chairani et al. 2007). So that according to Wang et al. (2006) who said that the first response of crop to $\mathrm{Al}^{3+}$ poisoning was root tissue damage, so that contributed to nutrient absorption decrease. Besides, $\mathrm{AL}^{3+}$ also gave bad effect to structure and function of leaves as photosynthesis machine and showed leaf
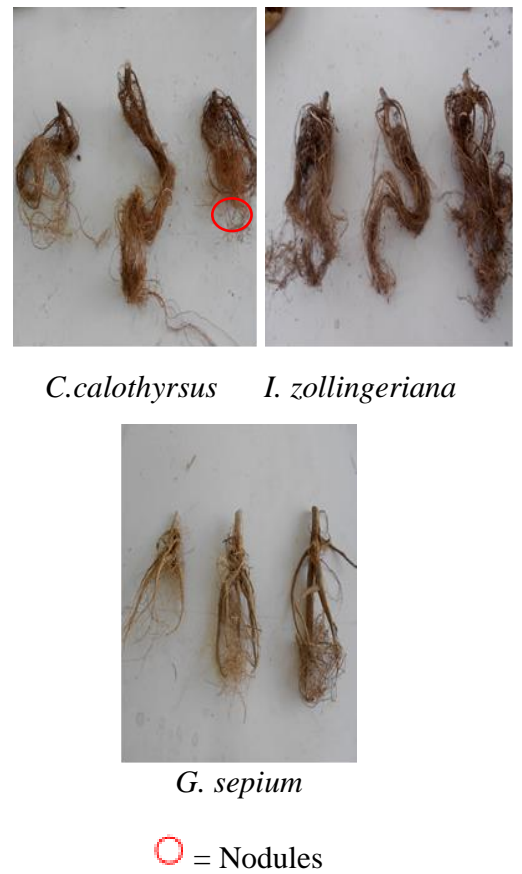

Figure 3. Root morphology on the acid soil

necrosis, so that assimilation process not running optimally (Zhang et al. 2007).

The highly growth and extension of root under acid soil stress showed higher tolerance than its adaptation to acid soil (nutrient deficiency) with high aluminum content (Polania et al. 2010). Based on Atman (2006), general characteristics of acid soil were $\mathrm{pH}$ value of the soil less that 4; low nutrient content of soil organic matter (SOM); low of $\mathrm{P}$ availability and Cation Exchange Capacity (CEC) of soil; high content of $\mathrm{Mn}^{2+}$ and reactive aluminum $\left(\mathrm{Al}^{3+}\right)$ that may poison the root and inhibit nodule forming of the legumes. Sudaryono (2009) said that former coal mine land showed $\mathrm{pH}$ around 4.4-5.3 was indicated as acid soil, whereas 4.24.3 of $\mathrm{pH}$ was indicated as very acid soil. The decrease in root growth is one of the initial and most evident symptoms of Altoxicity at micromolar $(\mu \mathrm{M})$ concentrations in plants (Rengel \& Zhang 2003).

\section{$\mathrm{AL}^{3+}$ concentration of crops tissue in the acid soil}

Average $\mathrm{Al}^{3+}$ concentration in tissue of leaves, stems, and roots of I. zollingeriana was significantly lowest $(\mathrm{P}<0.05)$ than $C$. callothyrsus and $G$. sepium (Table 2). The highest $\mathrm{Al}^{3+}$ concentration was in the part of root tissue. This was because of the root was a part of crop tissue which directly contacted with rizosphere (acid soil), so that $\mathrm{Al}^{3+}$ concentration was accumulated more in the part of that tissue, whereas it was relatively low in the tissue. 
Table 2. $\mathrm{Al}^{3+}$ concentration of tissue of the three legumes

\begin{tabular}{lccc}
\hline \multirow{2}{*}{ Legume } & \multicolumn{3}{c}{$\mathrm{Al}^{3+}$ concentration $(\mathrm{mg} / \mathrm{kg})$} \\
\cline { 2 - 4 } & Leaf & Stem & Root \\
\hline C. callothyrsus & $0.21^{\mathrm{b}}$ & $26.71^{\mathrm{b}}$ & $83.65^{\mathrm{b}}$ \\
I. zollingeriana & $0.13^{\mathrm{c}}$ & $14.33^{\mathrm{c}}$ & $47.77^{\mathrm{c}}$ \\
G. sepium & $0.35^{\mathrm{a}}$ & $52.18^{\mathrm{a}}$ & $135.51^{\mathrm{a}}$ \\
\hline
\end{tabular}

Not equal letter in the same column shows a significantly difference $(\mathrm{P}<0.05)$

Poisoning symptom was seen from $\mathrm{Al}^{3+}$ accumulation in the G. sepium tissue, or this crop was not tolerance and disable to eliminate the $\mathrm{Al}^{3+}$ accumulation. I. zollingeriana and $C$. callothyrsus was able to eliminate the $\mathrm{Al}^{3+}$ accumulation on all tissue, so both of the crops still show good morphology character. Delhaize \& Ryan (1995) said that crop which tolerance to the Al stress, was a crop which able to accumulate Al fewer, so that Al toxicity was relatively low.

In the soil containing of high aluminum saturation such as several areas in Indonesia, G. sepium grew poorly and had low survival. However, Nusantara (2009) said that Gliricidia crop was suitable for acid and marginal soils. According to Zang et al. (2007), aluminum in low concentration in soil was very helpful to the growth and would be toxic to the crop only when the concentration exceeds a certain threshold. Furthermore, he said that the highest threshold of the Al concentration was $800 \mathrm{mg} / \mathrm{kg}$ in the soil caused decreasing of chlorophyll content of leaves, so that assimilation process was disturbed caused crop productivity decrease. Soil used for this study was 1.26 mol or $34000 \mathrm{mg} / \mathrm{kg}$ (Table 1). Ying et al. (2006) reported that low aluminum concentration did not affect or increased the crops growth. On the contrary, Liu et al. (2006), in his study showed that surface area and dry weight of leaves of 2 soybean cultivars increased on the $\mathrm{Al}$ concentration treatment as much as $200 \mathrm{mg} / \mathrm{kg}$. Furthermore, on the aluminum concentration of 200 $400 \mathrm{mg} / \mathrm{kg}$, the crops started showing assimilation rate decreasing caused by leaf stomata closing. Chen et al. (2006), states that with increasing content of $\mathrm{Al}^{3+}$ on the roots and leaves cause the concentration of $\mathrm{Mg}$ in the two organs decreases, consequently photosiyntetic active radiation (PAR) was declined.

According to Soemarno (2005), Al concentration in soil solution was very high when soil $\mathrm{pH}$ was low. $\mathrm{pH}$ value increased on waterlogged soil and $\mathrm{Al}$ concentration on soil solution decreased under critical level of $\mathrm{Al}$ poisoning. $\mathrm{Al}$ stress treatment at $\mathrm{Al}$ saturation index of $25 \%$ and $50 \%$ decreased dry weight of root of 5 soybean genotypes and increased dry weight of Wilis root. The size of the dry weight decreasing of root depended on type of genotype (Hanum et al. 2007).

\section{Crops growth in the acid soil}

Result of analysis of variance showed that $C$. callothyrsus was significantly $(\mathrm{P}<0.05)$ highest tree $(122.47 \mathrm{~cm})$ than $I$. zollingeriana $(96.34 \mathrm{~cm})$ and $G$. sepium $(62.83 \mathrm{~cm})$ in 44 weeks old (Table 3$)$. Stem diameter of $I$. zollingeriana was significantly $(\mathrm{P}<0.05)$ higher by $10.21 \mathrm{~mm}$ compared to $C$. callothyrsus and $G$. sepium by 8.99 and $7.54 \mathrm{~mm}$ respectively, whereas stem diameter of $C$. callothyrsus and $G$. sepium was not significantly different. Average number of branches of I. zollingeriana was significantly $(\mathrm{P}<0.05)$ the most by 35.92 branches compared to the other crops, and the lowest was in G. sepium by 7.65 branches.

C. callothyrsus root was significantly $(\mathrm{P}<0.05)$ longer by $70.36 \mathrm{~cm}$ compared to G. sepium root by $27.19 \mathrm{~cm}$, but it was not significantly different compared to the I. zollingeriana. According to Sumarno (2005), very clear symptoms from the crops which sensitive to acid soil were very stunted growth, tawny leaves, limited rooting growth, flower and seed number forming was minimal, very low productivity or even failed to produce seed. Silveira (2013) said that negative effect of soil acidity to forage growth generally not caused by single factor, but by several factors, which affected normally crops growth. The main factor commonly affected crops growth in the acid soil consisting of toxicity of Hydrogen ion $\left(\mathrm{H}^{+}\right)$, aluminum, mangan and essential nutrient deficiency such as phosphor, magnesium, and micronutrient.

Table 3. Growth of the three legumes in the acid soil in 44 weeks old

\begin{tabular}{lcccc}
\hline \hline \multirow{2}{*}{ Legume } & \multicolumn{3}{c}{ Growth Parameter } \\
\cline { 2 - 5 } & High $(\mathrm{cm})$ & Stem diameter $(\mathrm{mm})$ & Average number of branches & Root length $(\mathrm{cm})$ \\
\hline C. callothyrsus & $122.47^{\mathrm{a}}$ & $8.99^{\mathrm{b}}$ & $15.88^{\mathrm{b}}$ & $70.36^{\mathrm{a}}$ \\
I. zollingeriana & $96.34^{\mathrm{b}}$ & $10.21^{\mathrm{a}}$ & $35.92^{\mathrm{a}}$ & $69.54^{\mathrm{a}}$ \\
G. sepium & $62.83^{\mathrm{c}}$ & $7.54^{\mathrm{b}}$ & $7.65^{\mathrm{c}}$ & $27.19^{\mathrm{b}}$ \\
\hline
\end{tabular}

Not equal letter in the same column shows a significantly difference $(\mathrm{P}<0.05)$ 
Aluminum was one of soil elements which able to cause poisoning to surrounding plants environment and inhibited the crops growth (Timotiwu 2010). In line with that, Hadiatmi (2002) said that clear symptoms in the shorgum were stunted growth, dwarf, thicker leaves and were dark green with outskirts purplish leaves or dried. Growth of crops rooting very depended on environment and controlled by activity of the crops. Daniel (2011) said that characteristics of aluminum toxicity symptom included of root defects such as thickened, twisted, short root tip and lateral roots, brown root, and did not have a good branching in rooting system.

According to Rout et al. (2001), Al caused disruption of cell fission on root cap and lateral root, cell rigidity through formation of pectin crosslink on the cell wall, and reduced DNA replication through increasing of double chain rigidity. Haling et al. (2011) said that growth and development of big and long crop root under acid land stress showed that capability of tolerance and adaptation to the acidity and saturation of high Al. The first and most recognized effect of Altoxicity in plants is the inhibition of the division and elongation of meristematic cells and thereby the reduction in root growth (Panda et al. 2003). In line with that, Yoichiro \& Midori (2011) said that length root was tolerance indicator of the crops to stress level of aluminum poisoning. Tolerant crops to aluminum would grow well, whereas root of sensitive crops would grow shorter and thick.

\section{Crops production in the acid soil}

Dry weight production of $I$. zollingeriana leaves was significantly $(\mathrm{P}<0.05)$ higher by $19.23 \mathrm{~g} / \mathrm{crop}$ compared to $C$. callothyrsus and $G$. sepium by 15.30 and $9.37 \mathrm{~g} / \mathrm{crop}$, respectively (Table 4). Dry weight production of $C$. callothyrsus branch/stem was significantly $(\mathrm{P}<0.05)$ higher by $13.39 \mathrm{~g} / \mathrm{crop}$ than $\mathrm{G}$. sepium by $10.20 \mathrm{~g} / \mathrm{crop}$, but dry weight production of branch/stem of I. zollingeriana and C. callothyrsus was not different.

Dry weight production of I. zollingeriana biomass was significantly $(\mathrm{P}<0.05)$ higher by $32.06 \mathrm{~g} / \mathrm{crop}$ compared to $C$. callothyrsus and $G$. sepium by 28.70 and $19.58 \mathrm{~g} / \mathrm{crop}$, respectively. Leaves/stems ratio of $I$. zollingeriana was significantly $(\mathrm{P}<0.05)$ higher by 3.44 compared to $C$. callothyrsus and $G$. sepium by 1.59 and 1.23 , respectively. Generally, dry weight production of I. zollingeriana was highest than $C$. callothyrsus and $G$. sepium. Chen (2006) and Dewi et al. (2010) said that $\mathrm{Al}$ toxicity was the main factor which inhibited crop's productivity in various acid soil throughout the tropics and subtropics. According to Chen et al. (2005b), aluminum stress caused closure of stomata which was responsible to decreasing of $\mathrm{CO}_{2}$ intake, so that the assimilation rate decrease. It affected decreasing of crop production drastically.

Ma et al. (2002) said that high Al concentration could disturb soybean growth and damage the rooting, so that absorption of nutrient and water was not optimal and caused low productivity of the crop. Based on Hilman et al. (2004), in the acid land, phosphate (P) availability became the major obstacle to increase. Type of the soils was toxic to crops and needed treatments. At $\mathrm{pH} \leq 5.5$, Al-toxicity is the main stress factor for plants which limits crop production (Ryan \& Delhaize 2010) legume production. Haling et al. (2011), good crop performance under stress of acid soil and drought was caused by capability to tolerate the stress which was implemented in biomass production of canopy and root which was connected with acquisitions level of nutrient and water. Chen et al. (2005a) said that Al decreased $\mathrm{CO}_{2}$ intake useful in the assimilation process of tangerines (Citrus rehhni), which affected to enzyme activity involved in Calvin cycle. The disruption of the assimilation cycle due to the $\mathrm{Al}$ induction caused decreasing of nutrition supply to the crop and decreased the production and quality of crop, especially to the sensitive crop. According to Lynch (2013), tolerant crops showed better rooting performance and it was expected would produce higher biomass. Al-toxicity results in alterations of the physiological and biochemical processes of plants and consequently their productivity (Mora et al. 2006).

\section{Nutrition content and digestibility value of the legumes in the acid soil}

Crude protein content (Table 5) of I. zollingeriana was significantly $(\mathrm{P}<0.05)$ highest by $21.80 \%$ compared to $C$. callothyrsus and G. sepium by 16.80 and 16.64 respectively.

Table 4. Average production per harvest of the three legumes in the acid soil

\begin{tabular}{|c|c|c|c|c|}
\hline \multirow{2}{*}{ Legume } & \multicolumn{3}{|c|}{ Dry weight production (g/crop) } & \multirow{2}{*}{$\begin{array}{c}\text { Ratio } \\
\text { Leaves/stems }\end{array}$} \\
\hline & Leaves & Stems & Biomass & \\
\hline C. callothyrsus & $15.30^{\mathrm{b}}$ & $13.39^{\mathrm{a}}$ & $28.70^{\mathrm{b}}$ & $1.59^{\mathrm{b}}$ \\
\hline I. zollingeriana & $19.23^{\mathrm{a}}$ & $12.83^{\mathrm{a}}$ & $32.06^{\mathrm{a}}$ & $3.44^{\mathrm{a}}$ \\
\hline G. sepium & $9.37^{\mathrm{c}}$ & $10.20^{\mathrm{b}}$ & $19.58^{\mathrm{c}}$ & $1.23^{\mathrm{c}}$ \\
\hline
\end{tabular}

Not equal letter in the same column shows a significantly difference $(\mathrm{P}<0.05)$ 
Table 5. Nutrient content and digestibility value of in vitro of the three legumes

\begin{tabular}{|c|c|c|c|c|c|c|c|c|c|}
\hline \multirow{2}{*}{ Legume } & \multicolumn{6}{|c|}{ Nutrient content } & \multirow{2}{*}{$\begin{array}{l}\text { Gross Energy } \\
(\mathrm{Kcal} / \mathrm{kg})\end{array}$} & \multicolumn{2}{|c|}{$\begin{array}{c}\text { Digestibility } \\
\text { value }(\%)\end{array}$} \\
\hline & $\mathrm{CP}(\%)$ & $\mathrm{CF}(\%)$ & CFat (\%) & Ash (\%) & $\mathrm{Ca}(\%)$ & $\mathrm{P}(\%)$ & & DMD & OMD \\
\hline C. callothyrsus & $16.80^{\mathrm{b}}$ & $30.98^{\mathrm{a}}$ & $4.06^{\mathrm{a}}$ & $4.18^{\mathrm{b}}$ & $0.42^{\mathrm{b}}$ & $0.14^{\mathrm{b}}$ & $4.472^{\mathrm{a}}$ & $59.89^{c}$ & $54.54^{\mathrm{b}}$ \\
\hline I. zollingeriana & $21.80^{\mathrm{a}}$ & $23.14^{\mathrm{b}}$ & $3.59^{\mathrm{b}}$ & $6.62^{\mathrm{a}}$ & $1.17^{\mathrm{a}}$ & $0.35^{\mathrm{a}}$ & $4.184^{\mathrm{b}}$ & $73.75^{\mathrm{b}}$ & $76.22^{\mathrm{a}}$ \\
\hline G. sepium & $16.64^{\mathrm{b}}$ & $23.08^{\mathrm{b}}$ & $4.38^{\mathrm{a}}$ & $6.08^{\mathrm{a}}$ & $0.75^{\mathrm{b}}$ & $0.14^{\mathrm{b}}$ & $4.162^{\mathrm{b}}$ & $78.02^{\mathrm{a}}$ & $76.88^{a}$ \\
\hline
\end{tabular}

Not equal letter in the same column shows a significantly difference $(\mathrm{P}<0.05)$

$\mathrm{CP} \quad=$ Crude Protein

$\mathrm{CF} \quad=$ Crude Fiber

CFat = Crude Fat

DMD = Dray Matter Digestibility

OMD = Organic Matter Digestibility

In line with Yayneshet et al. (2009) who said that crude protein content of the forage on the semi-acid land in Ethiopia was decrease drastically caused by stress of drought and soil acidity. Binding of $\mathrm{Al}^{3+}$ to cell membrane phospholipids and transport proteins, reduces the net negative membrane surface charge, permitting the movement of anions and restricting that of cations (Huang et al.1992). The highest fiber content was reached by $C$. callothyrsus by $30.98 \%$ followed by I. zollingeriana and G. sepium by 23.14 and $23.08 \%$ respectively.

Higher content of structural component (NDF, ADF, and ADL) was found during dry season, especially in the acid soil possibility was caused by lignification height and stadium of crop maturity (Hussain \& Durrani 2009).

Ash content of $I$. zollingeriana was significantly $(\mathrm{P}<0.05)$ different with $C$. callothyrsus but significantly not different with the G. sepium. Similarly, $\mathrm{Ca}$ and $\mathrm{P}$ content of I. zollingeriana was significantly $(\mathrm{P}<0.05)$ different with $C$. callothyrsus and $G$. sepium, but $\mathrm{Ca}$ and $\mathrm{P}$ content of $C$. callothyrsus was significantly not different with G. sepium. As said by Zhao et al. (2009) that ash level referred to mineral content closely related to soil condition, soil type, fertilizing and irrigation. Furthermore, Silveira (2013) said that negative effect of soil acidity to forage growth, generally not caused by single factor, but by several factors affected normally crop growth. The main factor generally affected crop growth in the acid soil included hydrogen ion $\left(\mathrm{H}^{+}\right)$ toxicity, aluminum, mangan, and deficiency of phosphor, magnesium, and micronutrient. Al content could inhibit absorption of essential nutrient, such as $\mathrm{Ca}, \mathrm{Mg}, \mathrm{Mn}, \mathrm{Fe}, \mathrm{Mo}$, and P (Poschenrieder et al. 2008). According to Silveira et al. (2011) optimum absorption of the most soil nutrient was occurred when the soil $\mathrm{pH}$ was close to neutral. Availability of several macronutrients $(\mathrm{N}, \mathrm{P}, \mathrm{K}, \mathrm{S}, \mathrm{Ca}$, and $\mathrm{Mg}$ ) decreased as an effect of soil acidity increase, so that lime application in the acid soil tended to increase nutrient availability. Al3 + is known to affect cell membrane structure and permeability by blocking the $\mathrm{Ca}^{2+}$ channels (Plieth 2005).

Yamamoto et al. (1992) said that inhibition of root growth and development due to $\mathrm{Al}^{3+}$ poisoning, in the long term could cause decreasing of capability to absorb the nutrient, suffering from nutrient $(\mathrm{P}, \mathrm{Ca}, \mathrm{Mg}$, or $\mathrm{Fe}$ ) deficiency, so that caused bad effect to the growth and development of the canopy. According to White \& Broadley (2003), Ca played important role as nutrient in the crops. As a divalent cation, $\mathrm{Ca}$ played role as structural wall and cell membrane participated in root and stem growth. Ca deficiency because of $\mathrm{Al}^{3+}$ content would affect crop production. Rout et al. (2001) mentioned that $\mathrm{Al}$-induced effects in leaves resemble $\mathrm{P}$ deficiencies.

Gross energy value of $C$. callothyrsus was significantly $(\mathrm{P}<0.05)$ higher by $4472 \mathrm{kcal} / \mathrm{kg}$ than $I$. zollingeriana and G. sepium by 4184 and $4162 \mathrm{kcal} / \mathrm{kg}$ respectively. According to Dewhurst et al. (2009), gross energy increase of the forage was always in line with dry matter increase, especially to organic matter. Varela de Arruda \& Fernandes (2014) said that there was a significant interaction between digestibility of dry material (DM) and gross energy (GE) of the forage which was affected metabolism energy value. Furthermore, it was said by Khachatur (2006) that total content of dry matter of grass that experienced abiotic stress decreased in line with the stress level, as well as its gross energy content.

Digestibility of $G$. sepium in vitro was significantly $(\mathrm{P}<0.05)$ highest by $78.02 \%$ compared to $I$. zollingeriana and G. sepium by 73.75 and $59.89 \%$ respectively. Furthermore, digestibility of in vitro organic matter of $G$. sepium was significantly not different with I. zollingeriana (76.88 vs 76.22$)$, but it was significantly $(\mathrm{P}<0.05)$ higher than $C$. callothyrsus $(54.54 \%)$. Digestibility value of in vitro dry matter was the number of dry matter, which could be digested and not excreted in the form of fesses, and it was assumed as absorbed part by the animal (Chuzaemi \& Bruchem 1990). According to González \& Hanselka (2002), 
digestibility value of organic matter of the forage, from wet season to dry season experienced significant decreasing in line with concentration increase of several fiber-forming components. Based on Nisa et al (2004), digestibility value of grass and legume, generally experienced a decreasing by age increase of the plant and soil water content due to concentration increase of crude fiber in the crop tissue, lignification increase, and leaves/stems ratio decrease. Mora et al. (2006) reported that high concentration of $\mathrm{Al}^{3+}$ correlated with poor quality of pasture and the higher risk was body weight gain decrease of the animals.

Based on analysis test of nutrient content, all of the legumes planted on the acid soil experienced decreasing from normal condition. Average content of Crude protein of $C$. calothyrsus by $20.0,23.1$, and $25.7 \%$ respectively (Tangendjaja et al. 1991; Tangendjaja et al. 1992; Herdiawan et al. (2014). The smallest crude protein decrease was showed by $I$. zollingeriana or become more resistant to acid soil. This may be caused by low cation exchange capacity, so that nutrient absorption experienced small obstacles. Other possibility was a root tissue structural damage caused by $\mathrm{Al}^{3+}$ poisoning, so that root absorption effectivity to water and nutrient in the soil was decrease (Khan et al. 2008). Optimum absorption of partly nutrients was occurred when soil $\mathrm{pH}$ was close to neutral. Availability of several macronutrients $(\mathrm{N}, \mathrm{P}, \mathrm{K}, \mathrm{S}, \mathrm{Ca}, \mathrm{Mg}$ ) decreased as an effect of increasing of soil acidity, so that lime application in the soil acid tented to increase nutrient availability to corn crop (Baligar et al. 1997). It has been reported that $\mathrm{Al}$ inhibits the absorption of nutrients, especially $\mathrm{Ca}, \mathrm{Mg}, \mathrm{Fe}$ and $\mathrm{Mo}$ and less available P (Poschenrieder et al. 2008).

\section{CONCLUSION}

$\mathrm{Al}^{3+}$ concentration of $I$. zollingeriana was lower than $C$. calothyrsus or that crop was tolerant to acid soil. Conversely, G. sepium was not tolerant causing low growth and productivity. $\mathrm{AL}^{3+}$ effect was also seen on root morphology, where nodule forming was only occurred on I. zollingeriana. C. callothyrsus root was longer with more root hairs resembling I. zollingeriana, whereas $G$. sepium root was shorter and the root hair was fewer. C. callothyrsus was more tolerant to $\mathrm{Al}^{3+}$ than G. sepium. Crop height measurement showed that C. calothyrsus was highest, but the stem diameter and the number of the highest branches was found on $I$. zollingeriana. The highest biomass was found on $I$. zollingeriana, whereas the fewer biomasses were found on $G$. sepium. Data analysis of nutrient value also showed that I. zollingeriana was tolerant to the acid soil and could be developed in that environment.

\section{REFERENCES}

Atman. 2006. Pengelolaan tanaman kedelai di lahan kering masam. Jurnal Ilmiah Tumbuhan. 5:281-287.

Baligar VC, Pitta GPE, Gama EEG, Schaffert RE, Afde C, Filho B, Clark RB. 1997. Soil acidity effects on nutrient use efficiency in exotic maize genotypes. Plant Soil. 192:9-13

Chairani H, Wahyu Q. Mugnisjah, Sudirman Y, Sopandy D, Idris K, Sahar A. 2007. pertumbuhan akar kedelai pada cekaman aluminium, kekeringan dan cekaman ganda aluminium dan kekeringan. Agritrop. 26:13-18.

Chen LS, Qi YP, Liu XH. 2005a. Effects of aluminum on light energy utilization and photoprotective systems in citrus leaves. J Ann Bot. 96:35-41.

Chen LS, Qi YP, Smith BR, Liu XH. 2005b. Aluminuminduced decrease in $\mathrm{CO} 2$ assimilation in citrus seedlings is unaccompanied by decreased activities of key enzymes involved in $\mathrm{CO} 2$ assimilation. Tree Physiol. 25:317-324

Chen LS. 2006. Physiological responses and tolerance of shoot to aluminum toxicity. J Plant Physiol Mol Biol. 32:143-155.

Chuzaemi S, Bruchem JV.. 1990. Fisiologi Nutrisi Ruminansia. KPK UGM - Brawijaya. Program Pasca Sarjana. Spesialisasi Pakan Ternak. Malang (Indonesia): Universitas Brawijaya.

Delhaize E, Ryan PR. 1995. Aluminium toxicity and tolerance in plants. Plant Physiol. 107:315-321.

Dewi IR, Miftahudin, Utut S, Hajrial A, Alex H. 2010. Karakter root re-rrowth sebagai parameter toleransi aluminium pada tanaman padi. J Natur Indones. 13:8288.

Dewhurst RJ, Delaby L, Moloney A, Boland T, Lewis E. 2009. Nutritive value of forage legumes used for grazing and silage. Irish J Agric Food Res. 48:167-187.

González VEA, Hanselka CW. 2002. Ecología y manejo de matorrales. Caso provincia biótica tamaulipeca. INIFAP-Texas A\&M University. Victoria (Mexico): Social and Comercial Press.

Hadiatmi. 2002. Evaluasi toleransi plasma nutfah sorghum terhadap lahan masam. Prosiding Kongres IV dan Simposium Nasional Perhimpunan Ilmu Pemuliaan Indonesia. Peripi Komda DIY dan Fakultas Pertanian Universitas Gadjah Mada, di Gedung Graha Sabha 1-3 Oktober 2002, Yogyakarta. p. 150-156.

Haling RE, Simpson RJ, Culvenor RA, Lambers H, Richardson A E. 2011. Effect of soil acidity, soil strength and macropores on root growth and morphology of perennial grass species differing in acidsoil resistance. Plant Cell Environment. 34:444-456.

Hanum C, Wahyu Q, Mugnisjah, Sudirman Y, Sopandy D, Idris K, Sahar A, 2007. Pertumbuhan akar kedelai pada cekaman aluminium, kekeringan dan cekaman ganda aluminium dan kekeringan. Agritrop. 26:13-18. 
Herdiawan I, Abdullah L, Sopandie D. 2014. Status nutrisi hijauan Indigofera zollingeriana pada berbagai taraf perlakuan stres kekeringan dan interval pemangkasan berbeda. JITV. 19:91-103.

Hilman Y, Kasno A, Saleh N. 2004. Kacang-kacangan dan umbi-umbian: Kontribusi terhadap ketahanan pangan dan perkembangan teknologinya. Makarim et al., penyunting. Inovasi pertanian tanaman pangan. Bogor (Indonesia): Pusat Penelitian dan Pengembangan Tanaman Pangan. hlm. 95-132.

Huang JW, Shaff JE, Grunes DL, Kochian LV. 1992. Aluminum effects on calcium fluxes at the root apex of aluminumtolerant and aluminum-sensitive wheat cultivars. Plant Physiol. 98:230-237.

Hussain F, Durrani MJ. 2009. Nutritional evaluation of some forage plants from Harboi arid Range land, Kalat, Pakistan. Pak J Bot. 41:1137-1154.

Kinraide T, Hagerman A. 2010. Interactive intoxicating and ameliorating effects of tannic acid, aluminum $\left(\mathrm{Al}^{3+}\right)$, copper $\left(\mathrm{Cu}^{2+}\right)$, and selenate $\left(\mathrm{SeO}_{4}{ }^{2-}\right)$ in wheat roots. A descriptive and mathematical assessment. Physiologia Plantarum. 139:68-79.

Khachatur MB. 2006. In- vitro digestible organic matter and energy contents in wild growing forages of Armenia. J Central Eur Agric. 7:445-449.

Khan HZ, Malik MA, Saleem MF. 2008. Effect of rate and source of organic material on the production potential of spring maize (Zea mays L.). Pak J Agric Sci. 45:40-43.

Liu P, Yang YS, Xu GD, Guo SL, Zheng XB, Wang M. 2006. Physiological response of four southern herbaceous plants to aluminum stress. Frontiers Biol China J. 3:295302.

Lynch JP. 2013. Steep, cheap and deep: an idiotype to optimize water and $\mathrm{N}$ aquisition by maize root systems. Ann Bot. 112:347-357.

Ma Q, Rengel, Z, Kuo J. 2002. Aluminium toxicity in rye (Secale cereale): root growth anddynamics of cytoplasmic $\mathrm{Ca} 2+$ in intact root tips. Ann Bot. 89:241244.

Gergichevich M, Alberdi M, Ivanov AG, Reyes-Díaz M. 2010. $\mathrm{Al}^{3+}-\mathrm{Ca}^{2+}$ Interaction in plants growing in acid soils: al-phytotoxicity response to calcareous amendments. J Soil Sci Plant Nutr. 10:217-243.

Mora ML, Alfaro MA, Jarvis SC, Demanet R, Cartes P. 2006. Soil aluminum availability in Andisols of Southern Chile and itseffect on forage production and animalmetabolism. Article first published online: 13 February 2006. Soil Use Manage. 22:95-101.

Mulyani A, Hikmatullah, Subagyo H. 2004. Karakteristik dan potensi tanah masam lahan kering di Indonesia. Prosiding Simposium Nasional Pendayagunaan Tanah Masam. Bogor (Indones): Balai Besar Sumberdaya Lahan Pertanian. hlm. 1-32.

Nisa M, M Sarwar, MA Khan. 2004. Influence of urea treated wheat straw with or without corn steep liquor on feed consumption, digestibility and milk yield and its composition in lactating Nili-Ravi buffaloes. AsianAust J Anim Sci. 17:825-830.

Nusantara S. 2009. Keunggulan gamal sebagai pakan ternak. Sembawa (Indones): BPTU Sembawa, Ditjen Peternakan dan Keswan. hlm. 1-48.

Panda SK, Singha LB, Khan MH. 2003. Does aluminium phytotoxicity induce oxidative stress in greengram (Vigna radiata). Bulg J Plant Physiol. 29:77-86.

Plieth C. 2005. Calcium: Just another regulator in the machinery of life?. J Ann Bot. 96:1-8.

Poschenrieder C, Gunsé B, Corrales I, Barceló J. 2008. A glance into aluminum toxicity and resistance in plants. Sci Total Environ. 400:356-368

Rengel Z. 1996. Uptake of aluminium by plant cells. New Phytol. 134:389-406.

Rengel Z, Zhang WH. 2003. Role of dynamics of intracellular calcium in aluminumtoxicity syndrome. New Phytol. 159:295-314

Rout GR, Samantara S, Das P. 2001. Aluminium toxicity in plants: a review. Agronomie. 21:3-21.

Ryan PR, Delhaize E. 2010. The convergent evolution of aluminium resistance in plants exploits a convenient currency. Funct Plant Biol. 37:275-284.

Schaberg PG, Tilley JW, Hawley GJ, Dehayes DH, Bailey SW. 2006. Associations of calcium and aluminum with the growth and health of sugar maple trees in Vermont. Forest Ecol Manag. 223:159-169.

Sopandie D. 2006. Perspektif fisiologi dalam pengembangan tanaman pangan di lahan marjinal. Orasi ilmiah guru besar tetap Fisiologi tanaman. Fakultas Pertanian. Institut Pertanian Bogor. hlm. 16-32.

Subagyo H, Suharta N, Siswanto AB. 2004. Tanah-tanah pertanian di Indonesia. Bogor (Indones): Balai Besar Sumberdaya Lahan Pertanian. hlm. 21-66.

Sudaryono. 2009. Tingkat kesuburan tanah ultisol pada lahan pertambangan batu bara Sangatta Kalimantan Timur. J Teknik Lingkungan. 10:337-346.

Sumarno. 2005. Strategi pengembangan kedelai di lahan masam. Makarim et al., penyunting. Prosiding Lokakarya Pengembangan Kedelai di Lahan Suboptimal. Bogor (Indones): Pusat Penelitian dan Pengembangan Tanaman Pangan. hlm. 37-46.

Suntoro, Hery W, Sudadi, Eko ES. 2014. Dampak abu vulkanik erupsi gunung kelud dan pupuk kandang terhadap ketersediaan dan serapan magnesium tanaman jagung di tanah alfisol. Jurnal Ilmu Tanah dan Agroklimatologi. 11:69-138.

Taiz L, Zeiger E. 2003. Plant physiology. 4th ed. Sunderland (UK): Sianuer Associates Inc., Publisher.

Timotiwu PB. 2010. Pengaruh tingkat keracunan alumunium terhadap perubahan gula yang dieksudasi oleh perakaran 
kedelai (Glycine $\max$ [L.] Merr.). Jurnal Agrotropika. 15:29-36.

Tjelele TJ. 2006. Dry matter production, intake and nutritive value of certain Indigofera spesies (Tesis). [Pretoria] University of Pretoria.

Utama MZH, Zen YM, Badal B, Hidayati S. 2005. Eksudasi dan akumulasi asam organik pada spesies legum penutup tanah sebagai mekanisme toleransi terhadap cekaman aluminium. Jurnal Stigma. 13:35-40.

Varela de Arruda AM, Fernandes RTV. 2014. Energetic value of forages from semi-arid region and digestibility of rations for naked neck pullets. Revista Caatinga. 27:232-238

Yamamoto Y, Ono K, Mametsuka K, Kasai M, Matsumoto H. 1992. Growth inhibition by aluminium is alleviated by phosphat starvation in cultured tobacco cells. Plant Cell Physiol. p. 404-406.

Yayneshet T, Eik LO, Moe SR. 2009. Seasonal variations in the chemical composition and dry matter degradability of enclosure forages in the semi-arid region of Northern Ethiopia. Anim Feed Sci Tech. 148:12-33.
Yoichiro K, Midori O. 2011. Root morphology, hydraulic conductivity and plant water relationsof high-yielding rice grown under aerobic conditions. Ann Bot. 108:575583.

Wang JP, Harsh R, Guo-Ping Z, Neville M, Zhou MX. 2006. Aluminium tolerance in barley (Hordeum vulgare L.): physiological mechanisms, genetics and screening methods. J Zhejiang Univ Sci B. 7:769-787.

White P, Broadley MR. 2003. Calcium in plants. J Ann Bot. 92:487-511

Ying XF, Liu P, Xu GD. 2006. Effect of aluminum on the isozymes of the seedlings of two soybeans [Glycine max (L.) Merrill] varieties. J Plant Soil Environ. 52:262-270.

Zhang XB, Liu P, Yang YS, Xu GD. 2007. Effect of Al in soil on photosynthesis and related morphological and physiological characteristics of two soybean genotypes. Botanic Studies. 48:435-444.

Zhao CX, He MR, Wang ZL, Wang YF, Lin Q. 2009. Effect of different water availability at post-anthesis stage on grain nutrition and quality in strong-gluten winter wheat. Comptes Rendus Biologies. 332:759-76. 
Herdiawan et al. Productivity of Calliandra calothyrsus, Indigofera zollingeriana, and Gliricidia sepium on acid soil in the greenhouse 